Open Access

\title{
Intratumoral and peritumoral post-irradiation changes, but not viable tumor tissue, may respond to bevacizumab in previously irradiated meningiomas
}

\author{
Motomasa Furuse*, Naosuke Nonoguchi, Shinji Kawabata, Tomo Miyata, Taichiro Toho, Toshihiko Kuroiwa
} and Shin-Ichi Miyatake

\begin{abstract}
The efficacy of bevacizumab has not been determined for treatment-refractory meningiomas. We treated meningiomas with low-dose bevacizumab and compared the radiological responses of non-irradiated meningiomas with previously irradiated meningiomas. In addition, we assessed intraparenchymal radiation necrosis following bevacizumab treatment. Six patients with meningiomas (three anaplastic, one atypical, and two grade I) who were previously treated with multiple sessions of radiotherapy and subsequently developed perilesional edema were treated with bevacizumab. Of six patients, two patients with anaplastic meningiomas developed three tumors following radiotherapy, which were defined as non-irradiated tumors. There were 12 pre-existing extra-axial tumors that were previously irradiated. Some of these tumors demonstrated adjacent intraparenchymal contrast enhancement. These tumors were defined as post-irradiated tumors. Four patients had intraparenchymal radiation necrosis. Low-dose bevacizumab was administered biweekly over 3-6 cycles to all patients.

Four tumors decreased in contrast-enhanced volume, nine tumors were unchanged, and two tumors progressed. Of the three non-irradiated tumors, two tumors increased in volume $(126 \%$ and $198 \%)$ and one tumor was stable $(-5 \%)$. The median reduction rates determined by contrast volume were $-31 \%$ and $-71 \%$ in post-irradiated tumors and radiation necrosis, respectively. Non-irradiated tumors had a significantly poorer response to bevacizumab than post-irradiated tumors and radiation necrosis ( $p=0.0013$ and $p=0.0005$, respectively, Tukey-Kramer test).

Low-dose bevacizumab did not demonstrate efficacy in the treatment of non-irradiated meningiomas. Responses to low-dose bevacizumab could be related to its effect on post-irradiation changes, rather than its effect on biologically active tumor tissue in post-irradiated meningiomas. Radiological responses to low-dose bevacizumab may distinguish biologically active tumors from post-irradiation changes in progressive meningiomas following radiotherapy.
\end{abstract}

Keywords: Anaplastic, Bevacizumab, Meningioma, Radiation necrosis

\section{Background}

High-grade meningiomas and benign skull base meningiomas are difficult to treat with surgical resection alone; therefore, these meningiomas are usually treated with surgical resection in combination with radiotherapy. In high-grade meningiomas, the efficacy of standard radiotherapy is limited and high-dose radiotherapy, including stereotactic radiosurgery, particle radiotherapy,

\footnotetext{
*Correspondence: neu054@poh.osaka-med.ac.jp

Department of Neurosurgery, Osaka Medical College, 2-7, Daigakumachi, Takatsuki, Osaka 569-8686, Japan
}

and repeated irradiation, is indispensable [1-3]. Unfortunately, these high-dose radiotherapies and multiple sessions of radiotherapy increase the frequency of radiation injury, including radiation necrosis. Chemotherapeutic agents are generally ineffective on meningiomas; however, two recent reports have demonstrated that anaplastic meningioma partially shrank after bevacizumab treatment [4, 5]. However, both tumors in this report had been previously irradiated, and intratumoral or peritumoral post-irradiation changes that caused angiogenesis may be mistaken for tumor tissue and incorrectly 
inferred as a response to bevacizumab. Some reports, including ours, have demonstrated that bevacizumab, which is an anti-vascular endothelial growth factor (VEGF) antibody, is effective in treating radiation necrosis of the brain [6-10]. VEGF is expressed in regions adjacent to necrotic cores of radiation necrosis, promoting angiogenesis and perilesional edema [11, 12]. It has also been reported that VEGF is expressed in meningiomas [13]. Distinguishing viable and active tumor tissues from post-irradiation changes by magnetic resonance (MR) imaging is challenging. Therefore, the true efficacy of bevacizumab treatment for either viable high-grade or treatment-refractory meningiomas remains unknown.

In the present study, we administered low-dose bevacizumab to patients with meningiomas previously treated with radiotherapy for the treatment of recently developed perilesional edema. Our aim of using bevacizumab treatment was initially to reduce perilesional edema and mass effect. At the commencement of bevacizumab treatment, some patients with anaplastic meninigomas developed new tumors, which had not been irradiated. We retrospectively evaluated the response of non-irradiated anaplastic meningiomas to bevacizumab. We also compared the response to bevacizumab between non-irradiated tumors and previously irradiated tumors, which may include intratumoral or peritumoral post-irradiation changes.

\section{Methods}

Six patients with meningiomas (three anaplastic, one atypical, and two grade I) were treated with bevacizumab between August 2012 and January 2014. All patients had undergone surgical resection and multiple sessions of radiotherapy, and recently developed massive perilesional edema. There were three non-irradiated tumors that had developed after radiotherapy in two patients with anaplastic meningiomas. These tumors were defined as "non-irradiated tumors." All patients had tumors that had been previously treated with radiotherapy. Some pre-existing extra-axial tumors were heterogeneously enhanced by contrast media and accompanied by adjacent parenchymal contrast-enhancement. These lesions likely represent both viable tumor tissue and post-irradiation changes and were defined as "post-irradiated tumors." There were 12 pre-existing extra-axial post-irradiated tumors in six patients. Four patients had intraparenchymal contrast-enhanced lesions that were not contiguous with extra-axial tumors. These lesions were defined as "radiation necrosis."

The initial aim of bevacizumab treatment was to reduce perilesional edema. Bevacizumab was intravenously administered at a dose of $5 \mathrm{mg} / \mathrm{kg}$ bi-weekly over 3-6 cycles. The time between the last radiotherapy session and the commencement of bevacizumab treatment ranged from 2.5 to 17 months (median 6 months). The response to bevacizumab was evaluated using volumetric analysis. The volume of a measurable extra-axial enhanced tumor or a measurable intraparenchymal enhanced radiation necrosis was calculated from the sum of the enhanced area on each slice of gadolinium-enhanced T1weighted MRI multiplied by the slice thickness. The volume of perilesional edema identified as hyperintense lesions on fluid attenuated inversion recovery (FLAIR) imaging was calculated in the same manner. The reduction rate due to bevacizumab was calculated by dividing the pre-treatment volume subtracted from the posttreatment volume by the pretreatment volume. "Response" was defined as a $50 \%$ reduction (-50\%). "Progression" was defined as a $25 \%$ increase $(25 \%)$. Lesions that were categorized as neither "response" nor "progression" (-49$24 \%$ ) were defined as "stable." The study protocol was approved by the Osaka Medical College Ethics Committee.

\section{Results}

Study patient demographics and tumor characteristics are shown in Table 1. Bevacizumab was administered for 6 cycles in two patients, 4 cycles in one patient, and 3 cycles in three patients. There were no apparent adverse events during bevacizumab treatment.

In all patients, perilesional edema improved following bevacizumab treatment. Perilesional edema reduced by between $-90 \%$ and $-29 \%$ compared to pretreatment edema (median $-46 \%$ ). The median change in contrast enhanced tumor volume of 15 meningiomas in response to bevacizumab was $-10 \%$ compared to pretreatment tumor volumes (range -89-198\%). Four tumors demonstrated a response according to tumor volume, nine tumors were stable, and two tumors progressed. Of three non-irradiated tumors, two tumors in Case 1 progressed (126\% and $198 \%$, respectively) (Fig. 1a, b, d, e) and one tumor in Case 2 was stable $(-5 \%)$ (Fig. 1c, f). On the other hand, all post-irradiated tumors were controlled by bevacizumab (Fig. 1c, f, Fig. 2a, b, d, e). The median reduction rate of post-irradiated tumors was $-31 \%(-89-19$ $\%)$. With regard to radiation necrosis, contrast-enhanced intraparenchymal lesions were decreased in all patients (Fig. 1c, f, Fig. 2a, c, d, f). The median reduction rate of radiation necrosis was $-71 \%(-100--51 \%)$ (Table 2$)$. There was a significant difference of the reduction rate between non-irradiated tumors, post-irradiated tumors, and radiation necrosis ( $p=0.0005$, ANOVA) (Fig. 3). Nonirradiated tumors responded significantly poorer than post-irradiated tumors and radiation necrosis $(p=0.0013$ and $p=0.0005$, respectively, Tukey-Kramer test). However, there was not a significant difference between postirradiated tumors and radiation necrosis $(p=0.3155$, Tukey-Kramer test). Clinically, the symptoms of three patients improved after bevacizumab, whereas those of the other three patients did not change. 
Table 1 Demographics of patients and tumors

\begin{tabular}{|c|c|c|c|c|c|c|c|c|c|c|c|c|}
\hline \multirow[t]{2}{*}{ Case } & \multirow{2}{*}{$\begin{array}{l}\text { Age } \\
\text { (years old) }\end{array}$} & \multirow[t]{2}{*}{$M / F$} & \multirow[t]{2}{*}{ Tumor } & \multirow{2}{*}{$\begin{array}{l}\text { Bev } \\
\text { (cycles) }\end{array}$} & \multirow[t]{2}{*}{ Lesion } & \multirow[t]{2}{*}{ Location } & \multirow[t]{2}{*}{ Radiotherapy } & \multirow{2}{*}{$\begin{array}{l}\text { Bev from } \\
\text { RT (month) }\end{array}$} & \multicolumn{2}{|c|}{ Reduction Rate } & \multicolumn{2}{|l|}{ Outcome } \\
\hline & & & & & & & & & FLAIR ( \%) & Gd (\%) & Radiological & Clinical \\
\hline \multirow[t]{4}{*}{ Case 1} & 70 & $\mathrm{~F}$ & anaplastic & 4 & $\begin{array}{l}\text { Tumor } 1 \\
\text { (non-irradiated) }\end{array}$ & R frontal (cranial) & & N/A & -71 & 198 & Progression & Improved L hemiparesis \\
\hline & & & & & $\begin{array}{l}\text { Tumor } 2 \\
\text { (non-irradiated) }\end{array}$ & R frontal (caudal) & & N/A & & 126 & Progression & \\
\hline & & & & & Tumor 3 & R frontal & SRT 32Gy & 8 & & -89 & Response & \\
\hline & & & & & Tumor 4 & R frontotemporal & $\begin{array}{l}\text { SRS 23Gy/SRS 20Gy/ } \\
\text { SRS 22Gy/ SRT 33Gy }\end{array}$ & 3 & & 7 & Stable & \\
\hline \multirow[t]{4}{*}{ Case 2} & 52 & M & anaplastic & 3 & Tumor 5 & occipital & $\begin{array}{l}\text { SRS 14Gy/ SRS 14Gy/ } \\
\text { SRT 25.5Gy/BNCT }\end{array}$ & 13 & -47 & -10 & Stable & $\begin{array}{l}\text { Unchanged dizziness and } \\
\text { visual disturbance }\end{array}$ \\
\hline & & & & & Tumor 6 & L temporal & SRT 27Gy & 20 & & -79 & Response & \\
\hline & & & & & $\begin{array}{l}\text { Tumor } 7 \\
\text { (non-irradiated) }\end{array}$ & R temporal & & N/A & & -5 & Stable & \\
\hline & & & & & Tumor 8 & L tentorial edge & SRS 20Gy & 2.5 & & -55 & Response & \\
\hline Case 3 & 76 & $\mathrm{~F}$ & atypical & 6 & Tumor 9 & parasagittal & SRT 24Gy/ BNCT & 8 & -29 & 0 & Stable & Unchanged $L$ hemiparesis \\
\hline Case 4 & 52 & M & grade I & 3 & Tumor 10 & petroclival & $\begin{array}{l}\text { GKR 14Gy/RT 30Gy/ } \\
\text { GKR 14Gy }\end{array}$ & 5.5 & -33 & -14 & Stable & $\begin{array}{l}\text { Improved } R \text { hemiparesis and } \\
L \text { ataxia }\end{array}$ \\
\hline Case 5 & 69 & $\mathrm{~F}$ & grade I & 3 & Tumor 11 & parasagittal & SRS/ SRS & 13 & -90 & -47 & Stable & Improved gait disturbance \\
\hline \multirow[t]{4}{*}{ Case 6} & 46 & $\mathrm{~F}$ & anaplastic & 6 & Tumor 12 & frontal base & EBRT 60Gy/ BNCT/BNCT & 4 & -45 & -48 & Stable & Unchanged cognitive dysfunction \\
\hline & & & & & Tumor 13 & orbit & $\mathrm{BNCT} / \mathrm{BNCT}$ & 4 & & -65 & Respose & \\
\hline & & & & & Tumor 14 & infratemporal & BNCT/BNCT & 4 & & 12 & Stable & \\
\hline & & & & & Tumor 15 & frontal convexity & EBRT 60Gy/ BNCT/BNCT & 4 & & 19 & Stable & \\
\hline
\end{tabular}




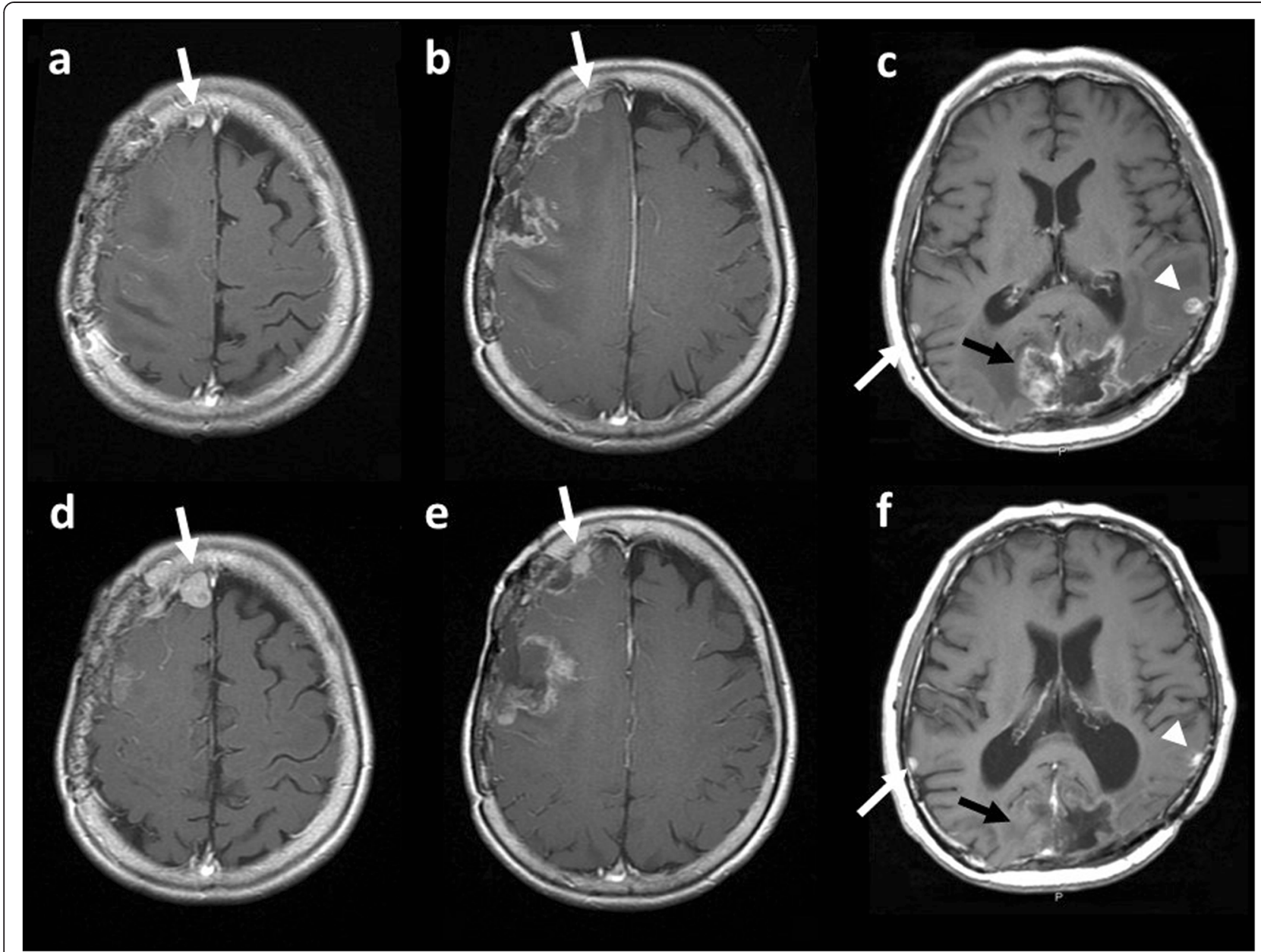

Fig. 1 MR images before and after bevacizumab in Case 1 (before, a, b; after, d, e) and Case 2 (before, c; after, f). There were three non-irradiated tumors (a, white arrow: tumor 1; b, white arrow: tumor 2; c, white arrow: tumor 7). After bevacizumab, both Tumors 1 and 2 showed progression (d, e: arrows). Tumor 7 did not changed after bevacizumab treatment (f: arrow). On the other hand, a post-irradiated tumor decreased after bevacizumab. Tumor 6 decreased to -79 \% (c, f: arrowheads). Intraparenchymal radiation necrosis was disappeared (c, f: black arrow)

\section{Discussion}

High-grade meningiomas and deep-seated benign meningiomas are difficult to manage. Any chemotherapeutic agent had not been shown to be effective on meningiomas [14-16]. Recently, there were some reports that bevacizumab was used for meningiomas (Table 3 ) $[4,5$, 17-20]. Lou et al. reported 14 cases of meningiomas treated with bevacizumab [5]. Ten of 14 patients had undergone prior radiotherapy, and bevacizumab was used as monotherapy in four patients and in combination with other chemotherapeutic agents in 10 patients. Treatment efficacy was evaluated using the Response Assessment in Neuro-Oncology [21]. There was no complete response $(\mathrm{CR})$, but a partial response (PR) in one patient, stable disease in 11 patients, and progressive disease in two patients were observed. The authors noted that there was a general trend toward increased progression-free survival in patients who had received stereotactic radiotherapy. In another case series, Nayak $\mathrm{L}$ et al. reported that grade II and III meningiomas were treated with bevacizumab [18]. Neither CR nor PR was obtained, and the best response was stable disease. There are two more case reports demonstrating that bevacizumab was used for malignant meningiomas [4, 20]. Both tumors had already irradiated before bevacizumab. The tumor partially responded to bevacizumab in one case and multiple tumors were stable or slowly growing after bevacizumab in the other case. There was no report that a non-irradiated anaplastic meningioma responded to bevacizumab. Nunes et al. treated neurofibromatosis type 2-related meningiomas with bevacizumab [19]. Fourteen patients had progressive vestibular schwannomas and coexisting meningiomas and one patient had progressive meningioma. They retrospectively analyzed the response to bevacizumab and found that tumor volume was reduced by $20 \%$ or more in $29 \%$ of 


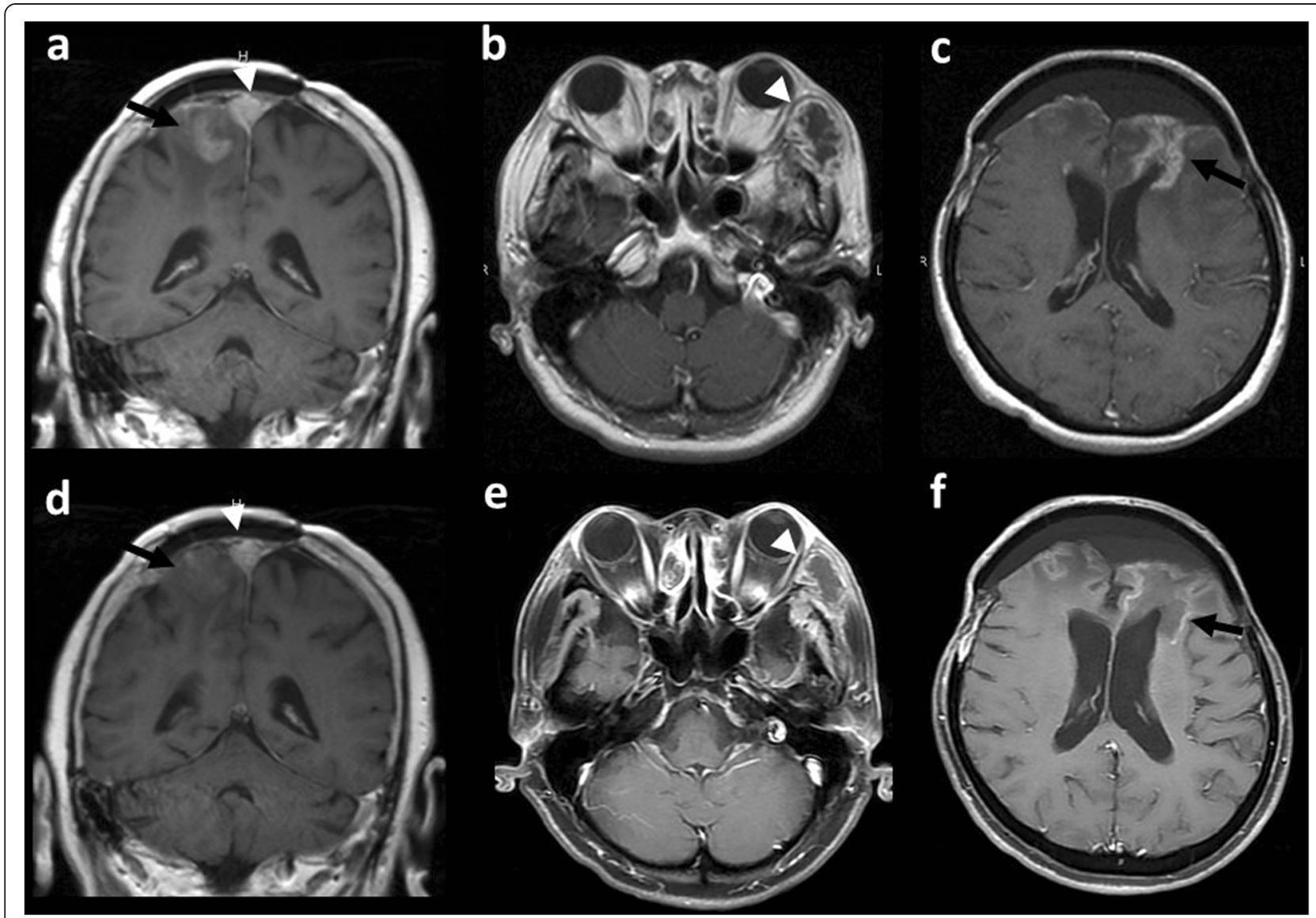

Fig. 2 MR images before and after bevacizumab in Case 3 (before, a; after, d) and Case 6 (before, b, c; after, e, f). Intraparenchymal radiation necrosis decreased to $-65 \%$ and $-51 \%$ after bevacizumab in Cases 3 and 6 , respectively (black arrows). Regarding post-irradiated tumors, Tumor 9 (Case 3) (a, d, arrowhead) did not change (0 \%) and Tumor 13 (Case 6) (b, e, arrowhead) showed $65 \%$ decrease after bevacizumab

meningiomas. $[4,17,20]$. Goutagny et al. also reported on the response of a coexisting convexity meningioma to bevacizumab in a patient with neurofibromatosis type 2 (the target of bevacizumab treatment was a vestibular schwannoma) [17]. The tumor size was reduced by $22 \%$ after bevacizumab. VEGF expression tended to increase with tumor grade; however, the difference did not reach statistical significance $[22,23]$. Conversely, the degree of VEGF expression has been reported to have a positive correlation with the extent of peritumoral edema [22, 24].

All of anaplastic meningiomas treated with bevacizumab in these reports were previously treated with radiotherapy. Our study had three non-irradiated anaplastic meningiomas and these tumors were not responded. Post-irradiated tumors responded to bevacizumab significantly better than non-irradiated tumors. Likewise, intraparenchymal radiation necrosis also significantly responded better than non-irradiated tumors. Therefore, we presume that enhancement by contrast, which is attenuated or disappears after bevacizumab treatment, may be an intratumoral or peritumoral postirradiation change. Our previous studies have shown that low-dose bevacizumab is also effective for radiation necrosis $[9,10]$. Low-dose bevacizumab is enough to

Table 2 Summary of intraparenchymal radiation necrosis

\begin{tabular}{|c|c|c|c|c|c|c|c|c|c|c|}
\hline Patients & $\begin{array}{l}\text { Age } \\
\text { (years old) }\end{array}$ & Gender & Tumor & $\begin{array}{l}\text { Bevacizumab } \\
\text { (cycles) }\end{array}$ & Lesion & Location & Radiotherapy & $\begin{array}{l}\text { Bev from RT } \\
\text { (month) }\end{array}$ & $\begin{array}{l}\text { Response } \\
\text { rate (\%) }\end{array}$ & $\begin{array}{l}\text { Radiological } \\
\text { assessment }\end{array}$ \\
\hline Case 2 & 52 & M & anaplastic & 3 & Necrosis 1 & occipital & $\begin{array}{l}\text { SRS 14Gy/ SRS 14Gy/ } \\
\text { SRT 25.5Gy/BNCT }\end{array}$ & 13 & -100 & Response \\
\hline Case 3 & 76 & $\mathrm{~F}$ & atypical & 6 & Necrosis 2 & parasagittal & SRT 24Gy/ BNCT & 8 & -65 & Response \\
\hline Case 5 & 69 & $\mathrm{~F}$ & grade I & 3 & Necrosis 3 & parasagittal & SRS/ SRS & 13 & -76 & Response \\
\hline Case 6 & 46 & $\mathrm{~F}$ & anaplastic & 6 & Necrosis 4 & frontal & EBRT 60Gy/ BNCT/BNCT & 4 & -51 & Response \\
\hline
\end{tabular}




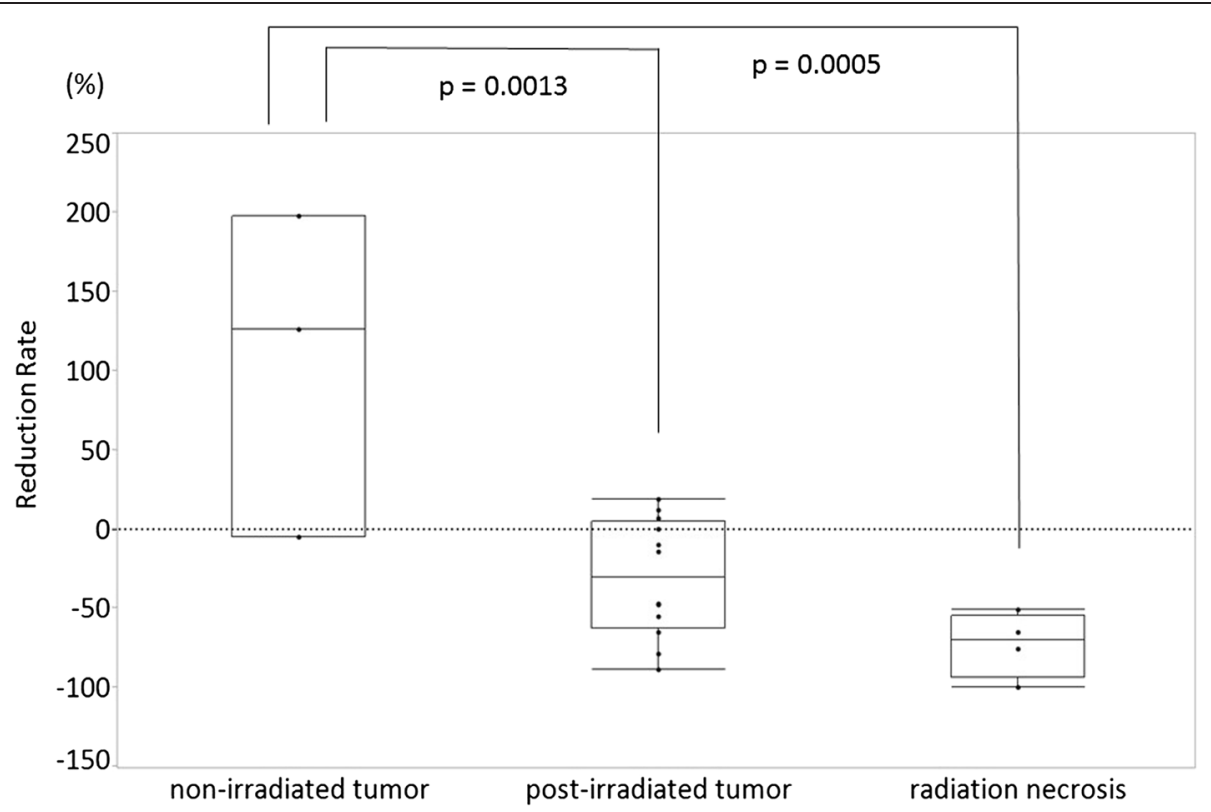

Fig. 3 Graph demonstrating the reduction rate of non-irradiated meningiomas, post-irradiated meningiomas, and intraparenchymal radiation necrosis. Non-irradiated tumors responded significantly poorer than post-irradiated tumors and radiation necrosis $(p=0.0013, p=0.0005$, respectively, Tukey-Kramer test)

reduce angiogenesis caused by post-irradiation changes, including radiation necrosis. In the present study, however, low-dose bevacizumab was not effective for treating non-irradiated anaplastic meningiomas. Post-irradiated tumors responded in various degrees to bevacizumab. The reason was that viable tumor tissue and postirradiation changes could be coexistent in tumors previously treated with radiotherapy and a section of postirradiation change may be influenced by reduction rate to bevacizumab. It is difficult to distinguish between these two pathologies in post-irradiated tumors using conventional MR sequences. However, the diagnostic ability of MRI has recently progressed. On diffusion-weighted MRI, the apparent diffusion coefficient reflecting cellular density has been shown to be useful in differentiating postirradiation effects from tumor recurrence or progression in high-grade gliomas [25]. Dynamic contrast-enhanced MR perfusion study has also shown its utility for distinguishing these two pathologies in gliomas [26]. In a recent study, multiparametric clustering MR imaging data demonstrated greater diagnostic accuracy in differentiating tumor progression from post-treatment change than did a single parameter method such as ADC or each perfusion parameter [27]. In diagnostic nuclear medicine, recurrent and progressive meningiomas show a high uptake of ${ }^{18} \mathrm{~F}$-FDG, ${ }^{11} \mathrm{C}$-methionine, and ${ }^{18} \mathrm{~F}$-boronophenylalanine on PET [28-30], and PET may differentiate between viable tumor tissues and post-irradiation changes in malignant meningiomas after radiation therapy. However, PET is not as widely available as MRI.
In our series, all patients showed progression of perilesional edema before bevacizumab treatment. In this condition, it is sometimes difficult to judge whether the main cause of perilesional edema is either tumor progression or post-irradiation changes. It could be to be desired that low-dose bevacizumab is firstly used to improve patients status when the lesion is not conclusively diagnosed as either a tumor progression or post-irradiation changes. In our study, half of the patient's neurological symptoms were ameliorated, reducing perilesional edema. Low-dose bevacizumab is expected to provide clinical benefits in patients with symptomatic perilesional edema irrespective of the pathology of the enhanced lesion. Low-dose bevacizumab could reduce contrast enhancement if a tumor includes post-irradiation changes. Residual enhanced lesion after bevacizumab may be mostly a viable tumor tissue. If bevacizumab is not effective and a large enhanced lesion still exists, then additional radiotherapy or surgical resection could be a treatment option to control disease. Preceding bevacizumab would avoid unnecessary additional radiotherapy for post-irradiated tumor.

\section{Conclusions}

Three non-irradiated anaplastic meningiomas did not respond to low-dose bevacizumab in our study. Some post-irradiated meningiomas responded to bevacizumab. Post-irradiated meningiomas had heterogeneous pathology; residual or recurrent active tumors coexisted with post-irradiation changes. Intratumoral and peritumoral post-irradiation changes, but not viable tumor tissue, 
Table 3 Review of literatures reporting bevacizumab treatment for meningiomas

\begin{tabular}{|c|c|c|c|c|c|c|c|c|}
\hline Authors & Tumor & Prior Tx & Bevacizumab & Treatment duration & $\begin{array}{l}\text { Radiological } \\
\text { assessment }\end{array}$ & Response & $\mathrm{PFS} / \mathrm{OS}$ & Toxicity \\
\hline $\begin{array}{l}\text { Putchner MJA, } \\
\text { et al. } 2010 \text { [4] }\end{array}$ & 1 Anaplstic & 60Gy RT & $\begin{array}{l}10 \mathrm{mg} / \mathrm{kg} \text { every } \\
2 \text { weeks }\end{array}$ & 6 months & N/A & $1 \mathrm{PR}$ & N/A & hypertension \\
\hline \multirow[t]{2}{*}{$\begin{array}{l}\text { Goutagny S, } \\
\text { et al. } 2011 \text { [17] }\end{array}$} & $\begin{array}{l}7 \text { tumors in } \\
\text { NF2 pts }\end{array}$ & none & $\begin{array}{l}5 \mathrm{mg} / \mathrm{kg} \text { Every } \\
2 \text { weeks }\end{array}$ & 15 months & volume & $\begin{array}{l}1 \text { tumor: } 22 \% \\
\text { decrease }\end{array}$ & N/A & No mention \\
\hline & & & & & & 6 tumors N/C & & \\
\hline \multirow[t]{4}{*}{$\begin{array}{l}\text { Lou E, et al. } \\
2012[5]\end{array}$} & $5 \mathrm{Gl}$ & RT: 12/14 & $\begin{array}{l}10 \mathrm{mg} / \mathrm{kg} \text { very } \\
2 \text { weeks }\end{array}$ & $0.5-29.5$ months & RANO & $0 \mathrm{CR}$ & mPFS: 17.9 months & Tumoral hemorrhage \\
\hline & $5 \mathrm{Gll}$ & CT: $11 / 14$ & & & & $1 \mathrm{PR}$ & PFS-6: $85.7 \%$ & G4 intestinal perforation \\
\hline & $3 \mathrm{GIII}$ & & & & & $11 \mathrm{SD}$ & & G5 pneumonia/sepsis \\
\hline & 1 unk & & & & & $2 \mathrm{PD}$ & & \\
\hline \multirow[t]{3}{*}{$\begin{array}{l}\text { Nayak L, et al. } \\
2012 \text { [18] }\end{array}$} & $6 \mathrm{GII}$ & RT: 15/15 & $\begin{array}{l}10 \mathrm{mg} / \mathrm{kg} \text { every } \\
2 \text { weeks }\end{array}$ & 9 doses (1-19 doses) & RANO & $0 \mathrm{CR}$ & mPFS: 26 weeks & G1 Intratumoral hemorrhage \\
\hline & $9 \mathrm{GIII}$ & $C T: 7 / 15$ & & & & $O P R$ & mOS: 15 months & G2 fatigue \\
\hline & & & & & & $15 \mathrm{SD}$ & & \\
\hline \multirow[t]{4}{*}{$\begin{array}{l}\text { Nunes FP, et al. } \\
2013 \text { [19] }\end{array}$} & $\begin{array}{l}48 \text { tumors } \\
\text { in } 15 \text { NF2 pts }\end{array}$ & & $\begin{array}{l}5 \mathrm{mg} / \mathrm{kg} \text { every } \\
2 \text { weeks }\end{array}$ & & $\begin{array}{l}\text { Response: } 20 \text { \% } \\
\text { reduction }\end{array}$ & $\begin{array}{l}\text { Tumor: } 29 \% \\
\text { response }\end{array}$ & Per-tumor & $4 \mathrm{G} 3$ events \\
\hline & & & & & $\begin{array}{l}\text { Progression: } 20 \% \\
\text { increase }\end{array}$ & Patients & PFS-6: 85 \% & $\begin{array}{l}2 \text { G4 events (wound } \\
\text { healing problems) }\end{array}$ \\
\hline & & & & & & $7 \%$ response & Per-patient & \\
\hline & & & & & & & PFS-6: $93 \%$ & \\
\hline \multirow[t]{2}{*}{$\begin{array}{l}\text { Boström JP, } \\
\text { et al. } 2014 \text { [20] }\end{array}$} & $1 \mathrm{GIII}$ & 60Gy RT & $\begin{array}{l}5 \mathrm{mg} / \mathrm{kg} \\
\text { every } 2 \text { weeks }\end{array}$ & 2 months & N/A & $\begin{array}{l}\text { Stable and } \\
\text { growing }\end{array}$ & N/A & No mention \\
\hline & & 35Gy SRT & & & & & & \\
\hline
\end{tabular}


may respond to low-dose bevacizumab in previously irradiated meningiomas. MR imaging after low-dose bevacizumab treatment could be used to differentiate active tumors from post-irradiation changes on the basis of the response of contrast enhanced lesions in post-irradiated meningiomas.

\section{Consent}

Written informed consent was obtained from all patients for the publication of this report and any accompanying images.

\section{Competing interests}

The authors declare that they have no competing interests.

\section{Authors' contributions}

MF drafted and wrote the manuscript. S-IM participated in the follow-up of patients. TM and TT collected the data. SK and NN carried out the statistical analysis, TK supervised and revised the manuscript. All authors read and approved the final manuscript.

\section{Acknowledgments}

This work was partly supported by a Grant-in-Aid for Scientific Research (C) (26462222) given to M.F. from the Japanese Ministry of Education, Culture, Sports, Science, and Technology.

Received: 26 March 2015 Accepted: 24 June 2015

Published online: 30 July 2015

\section{References}

1. Boskos C, Feuvret L, Noel G, Habrand JL, Pommier P, Alapetite C, et al. Combined proton and photon conformal radiotherapy for intracranial atypical and malignant meningioma. Int J Radiat Oncol Biol Phys. 2009:75:399-406.

2. Combs SE, Hartmann C, Nikoghosyan A, Jäkel O, Karger CP, Haberer T, et al. Carbon ion radiation therapy for high-risk meningiomas. Radiother Oncol. 2010:95:54-9.

3. Kawabata S, Hiramatsu R, Kuroiwa T, Ono K, Miyatake S. Boron neutron capture therapy for recurrent high-grade meningiomas. J Neurosurg. 2013;119:837-44.

4. Puchner MJA, Hans VH, Harati A, Lohmann F, Glas M, Herrlinger U. Bevacizumab-induced regression of anaplastic meningioma. Ann Oncol. 2010;21:2445-6.

5. Lou E, Sumrall AL, Turner S, Peters KB, Desjardins A, Vrendenburgh JJ, et al. Bevacizumab therapy for adults with recurrent/progressive meningioma: a retrospective series. J Neurooncol. 2012;109:63-70.

6. Gonzalez J, Kumar AJ, Conrad CA, Levin VA. Effect of bevacizumab on radiation necrosis of the brain. Int J Radiat Oncol Biol Phys. 2007;67:323-6.

7. Torcuator R, Zuniga R, Mohan YS, Rock J, Doyle T, Anderson J, et al. Initial experience with bevacizumab treatment for biopsy confirmed cerebral radiation necrosis. J Neurooncol. 2009;94:63-8.

8. Levin VA, Bidaut L, Hou P, Kumar AJ, Wefel JS, Bekele BN, et al. Randomized double-blind placebo-controlled trial of bevacizumab therapy for radiation necrosis of the central nervous system. Int J Radiat Oncol Biol Phys. 2011;79:1487-95.

9. Furuse M, Kawabata S, Kuroiwa T, Miyatake S. Repeated treatments with bevacizumab for recurrent radiation necrosis in patients with malignant brain tumors: a report of 2 cases. J Neurooncol. 2011;102:471-5.

10. Furuse M, Nonoguchi N, Kawabata S, Yoritsune E, Takahashi M, Inomata T, et al. Bevacizumab treatment for symptomatic radiation necrosis diagnosed by amino acid PET. Jpn J Clin Oncol. 2013;43:337-41.

11. Nordal RA, Nagy A, Pintillie M. Hypoxia and hypoxia-inducible factor-1 target genes in central nervous system radiation injury: a role for vascular endothelial growth factor. Cin Cancer Res. 2004;10:3342-53.

12. Nonoguchi N, Miyatake SI, Fukumoto M, Furuse M, Hiramatsu R, Kawabata S, et al. The distribution of vascular endothelial growth factor-producing cells in clinical radiation necrosis of the brain: pathological consideration of their potential roles. J Neurooncol. 2011;105:423-31.
13. Provias J, Claffey K, del Aguila L, Lau N, Feldkamp M, Guha A. Meningiomas: role of vascular endothelial growth factor/vascular permeability factor in angiogenesis and peritumoral edema. Neurosurgery. 1997;40:1016-26.

14. Chamberlain MC, Tsao-Wei DD, Groshen S. Temozolomide for treatment-resistant recurrent meningioma. Neurology. 2004;62:1210-2.

15. Norden AD, Raizer JJ, Abrey LE, Lamborn KR, Lassman AB, Chang SM, et al. Phase II trials of erlotinib or gefitinib in patients with recurrent meningioma. J Neurooncol. 2010;96:211-7.

16. Wen PY, Yung WK, Lamborn KR, Norden AD, Cloughesy TF, Abrey LE, et al. Phase II study of imatinib mesylate for recurrent meningiomas (North American brain tumor consortium study 01-08). Neuro Oncol. 2009;11:853-60.

17. Goutagny S, Raymond E, Sterkers O, Colombani JM, Kalamarides M. Radiographic regression of cranial meningioma in a NF2 patient treated by bevacizumab. Ann Oncol. 2011;22:990-1.

18. Nayak L, Iwamoto FM, Rudnick JD, Norden AD, Lee EQ, Drappatz J, et al. Atypical and anaplastic meningiomas treated with bevacizumab. J Neurooncol. 2012;109:187-93.

19. Nunes FP, Merker VL, Jennings D, Caruso PA, di Tomaso E, Muzikansky A, et al. Bevacizumab treatment for meningiomas in NF2: a retrospective analysis of 15 patients. PLoS One. 2013;8:e59941.

20. Boström JP, Seifert M, Greschus S, Schäfer N, Glas M, Lammering G, et al. Bevacizumab treatment in malignant meningioma with additional radiation necrosis. An MRI diffusion and perfusion case study. Strahlenther Onkol. 2014;190:416-21.

21. Wen PY, Macdonald DR, Reardon DA, Cloughesy TF, Sorensen AG, Galanis E, et al. Updated response assessment criteria for high-grade gliomas: response assessment in neuro-oncology working group. J Clin Oncol. 2010;28:1963-72.

22. Lee JW, Kang KW, Park SH, Lee SM, Paeng JC, Chung JK, et al. 18F-FDG PET in the assessment of tumor grade and prediction of tumor recurrence in intracranial meningioma. Eur J Nucl Med Mol Imaging. 2009;36:1574-82.

23. Ikeda H, Tsuyuguchi N, Kunihiro N, Ishibashi K, Goto T, Ohata K. Analysis of progression and recurrence of meningioma using (11)C-methionine PET. Ann Nucl Med. 2013;27:772-80.

24. Miyatake S, Tamura Y, Kawabata S, lida K, Kuroiwa T, Ono K. Boron neutron capture therapy for malignant tumors related to meningiomas. Neurosurgery. 2007;61:82-90.

25. Hein PA, Eskey CJ, Dunn JF, Hug EB. Diffusion-weighted imaging in the follow-up of treated high-grade gliomas: tumor recurrence versus radiation injury. AJNR Am J Neuroradiol. 2004;25:201-9.

26. Narang J, Jain R, Arbab AS, Mikkelsen T, Scarpace L, Rosenblum ML, et al. Differentiating treatment-induced necrosis from recurrent/progressive brain tumor using nonmodel-based semiquantitative indices derived from dynamic contrast-enhanced T1-weighted MR perfusion. Neuro-Oncol. 2011:13:1037-46.

27. Park JE, Kim HS, Goh MJ, Kim SJ, Kim JH. Pseudoprogression in patients with glioblastoma: assessment by using volume-weighted voxel-based multiparametric clustering of MR imaging data in an independent test set. Radiology. 2015;275:792-802.

28. Paek SH, Kim CY, Kim YY, Park IA, Kim MS, Kim DG, et al. Correlation of clinical and biological parameters with peritumoral edema in meningioma. J Neurooncol. 2002;60:235-45.

29. Panagopoulos AT, Lancellotti CL, Veiga JC, de Aguiar PH, Colquhoun A. Expression of cell adhesion proteins related to angiogenesis and fatty acid metabolism in benign, atypical, and anaplastic meningiomas. J Neurooncol. 2008:89:73-87.

30. Otsuka S, Tamiya T, Ono Y, Michiue H, Kurozumi K, Daido S, et al. The relationship between peritumoral brain edema and the expression of vascular endothelial growth factor and its receptors in intracranial meningiomas. J Neurooncol. 2004;70:349-57. 